\title{
Growth and Productivity of Brown Midrib Sorghum Mutant Line Patir 3.7 (Sorghum bicolor L. Moench) Treated with Different Levels of Nitrogen Fertilizer
}

\author{
R. Sriagtula*, S. Sowmen, \& Q. Aini \\ Department of Nutrition and Feed Technology, Faculty of Animal Science, Andalas University \\ Kampus Unand Limau Manis, Padang 25163, Indonesia \\ *Corresponding author: riesisriagtula@ansci.unand.ac.id \\ (Received 21-03-2019; Revised 13-05-2019; Accepted 27-05-2019)
}

\begin{abstract}
The study aimed to determine the best of nitrogen fertilizer level based on growth and biomass production of brown midrib sorghum mutant line Patir 3.7. This research was conducted at the Field Laboratory in the Faculty of Animal Science, Andalas University, Padang. The experiment was assigned in a completely randomized block design with 4 levels of nitrogen fertilizer application and 3 replications. The treatments consisted of $\mathrm{N} 0=0 \mathrm{~kg} \mathrm{~N} \mathrm{ha}^{-1}$ as a control; $\mathrm{N} 1=50 \mathrm{~kg} \mathrm{~N}^{-1} ; \mathrm{N} 2=100 \mathrm{~kg}$ $\mathrm{N} \mathrm{ha}^{-1}$; and N3=150 $\mathrm{kg} \mathrm{N} \mathrm{ha}^{-1}$. Agronomic and production variables measured were plant height, stem diameter, leaf width length, leaf stem panicle ratio, stem Brix sugar content, as well as fresh biomass and nutrient production. Analysis of variance followed by Duncan Multiple Range Test (DMRT) was conducted. The results showed that the addition of nitrogen fertilizer produced the highest stem diameter, leaf length, leaf width, leaf ratio, and stem ratio $(\mathrm{p}<0.05)$. However, the panicle ratio and stem Brix sugar contents were not significantly affected $(p>0.05)$ by the level of nitrogen fertilizer. The fresh biomass, dry matter, crude protein, ash, NFE, and TDN production increased significantly $(p<0.05)$ with the increased level of nitrogen fertilizer. Based on those findings, it can be concluded that nitrogen fertilizer application at the level of $50 \mathrm{~kg} \mathrm{~N} \mathrm{ha}^{-1}$ produces better growth, fresh biomass, dry matter, and nutrients production.
\end{abstract}

Keywords: biomass production; Brown midrib sorghum; nitrogen fertilizer; nutrient production

\section{INTRODUCTION}

Sorghum (Sorghum bicolor L. Moench) is the cereal crop ranked fifth globally after wheat, maize, rice, and barley. It is cultivated for a variety of purposes; the vegetative parts are used as green feed for ruminants and the grain as a food for both human and animal consumptions (Koten et al., 2012). Sorghum is a C4 plant that grows well in dry tropical climates and can also adapt well to diverse climatic and soil conditions. One variety of sorghum plants, known as sweet sorghum, has a high sugar content and potential as an alternative for animal feed. Sweet sorghum produces greater biomass than maize and can replace it as a livestock feed (Rocateli et al., 2012; Yu et al., 2008). Sorghum does not only contribute to forage (a source of fiber) but as a cereal plant, it also produces seeds as sources of protein and starch. However, due to high lignin content, the digestibility of conventional sweet sorghum is lower than that of maize that limits its use as animal feed.

One new type of sweet sorghum that has been developed to have a lower lignin content and hence has higher digestibility is brown midrib sorghum (BMR). Developed by an induced mutation using gamma-ray irradiation, this variety has been specifically developed as an animal feed and become widely used globally (Ouda et al., 2005). Patir 3.7 is one of BMR mutant-sorghum lines developed in Indonesia which produces a large amount of dry matter which can be increased further with a good and optimal fertilizer (Sriagtula et al., 2016).

Fertilizer plays an important role in maximizing agricultural yield. Using the optimal amount and nutrient content of fertilizer can increase growth, production, and nutritional content of plants. Nitrogen is an important nutrient for plants to maximize yields, especially in developing countries where yields are often very low (Good \& Beatty, 2011). The need for nitrogen is very high in feed crops, like grasses including sorghum. Sufficient nitrogen increases growth rate, production, and quality of forage plants.

Nitrogen is an essential macro-nutrient in the formation of chlorophyll and a constituent component of many essential compounds in plant tissues, for example in amino acids, proteins, and enzymes (Lakitan, 2004). The nitrogen availability is related to the use of the environment resources by the plants, such as solar radiation and water, and a further increase in dry matter production (Brambilla et al., 29012). Ideally, nitrogen fertilizer is an inorganic fertilizer that should be supplemented with an organic fertilizer in the form of manure which is rich in nitrogen. This form will build up the organic matter content and so improve the nature of the soil which will improve the growth of foliage plants such as sorghum.

The nitrogen fertilizer requirement in sorghum plants has been widely studied. Ayub et al. (2002) reported that in Pakistan, an increase in nitrogen fertilizer 
from $40-120 \mathrm{~kg} \mathrm{ha}^{-1}$ resulted in the increased of dry matter production in conventional sorghum. Another study applying nitrogen fertilizers at the level of $90-120 \mathrm{~kg} \mathrm{~N}$ $\mathrm{ha}^{-1}$ showed an increase in the growth of sorghum production (Uchino et al., 2013). The response of sorghum to nitrogen fertilizer depends on genotype, climatic conditions, and the nature of the soil (Kurai et al., 2015). The novelty of this study is the use of new BMR sorghum mutant line material as a result of mutation technology produced in Indonesia. Information about the response of BMR sorghum mutants to nitrogen fertilizer in Indonesia is still limited. The objective of this study was to determine the best level of nitrogen fertilizer for the BMR sorghum mutant line Patir 3.7 to maximize biomass production in a sustainable state.

\section{MATERIALS AND METHODS}

This research was conducted in the Experimental Laboratory, Faculty of Animal Science, Andalas University, Padang in July-October 2017. In this study, ultisol soil with a $\mathrm{pH}$ of 5.6 was used. Rainfall during the study was categorized as moderate at $100-300 \mathrm{~mm}$ to a high at 300-500 mm (Ishak et al., 2012). The soil analysis and climate condition during the study were presented in Table 1 and Figure 1. The materials used were the BMR sorghum mutant line Patir 3.7 obtained from the Silviculture Laboratory of SEAMEO-BIOTROP Bogor, manure, urea, trisodium phosphate (TSP), $\mathrm{KCl}$, scales, and pruning shears. Sidametrin brand pesticide was used to prevent pests.

Fertilizers used were TSP for $\mathrm{P}$ and $\mathrm{KCl}$ for $\mathrm{K}$ applied at a rate of $76.7 \mathrm{ha}^{-1}$ and $100 \mathrm{~kg} \mathrm{ha}^{-1}$, respectively (Turmudhi, 2010). Urea was used as a nitrogen fertilizer with the dose varied according to the selected treatment. This study used a randomized block design with 4 levels of nitrogen fertilizer application and 3 replications. The nitrogen fertilizer levels consisted of $\mathrm{N} 0=0 \mathrm{~kg} \mathrm{~N}$ $\mathrm{ha}^{-1}, \mathrm{~N} 1=50 \mathrm{~kg} \mathrm{~N} \mathrm{ha}^{-1}, \mathrm{~N} 2=100 \mathrm{~kg} \mathrm{~N} \mathrm{ha}^{-1}$, and N3=150 $\mathrm{kg} \mathrm{N} \mathrm{ha}^{-1}$. Harvesting was conducted at the soft-dough phase (90 days after sowing/DAS).

\section{Soil Processing}

Organic fertilizer was applied using 10 tons $\mathrm{ha}^{-1}$ of manure before planting. The size of the research plot was $20 \mathrm{~m}^{2}(4 \times 5 \mathrm{~m})$. The planting of sorghum seeds was carried out two weeks after tillage. A range of 4-5 sor-

Table 1. Soil characteristics

\begin{tabular}{lccc}
\hline Soil properties & Unit & Value & Information \\
\hline $\mathrm{pH}$ & $\mathrm{H} 2 \mathrm{O}$ & 5.6 & Medium \\
$\mathrm{C}$ & $\%$ & 1.8 & Low \\
Organic matter & $\%$ & 3.2 & Low \\
Cation exchange & $\mathrm{me} / 100 \mathrm{~g}$ & 16.3 & Low \\
capacity & & & \\
N-total & $\%$ & 0.3 & Low \\
P available & $\mathrm{Ppm}$ & 1.9 & Low \\
K-total & $\mathrm{me} / 100 \mathrm{~g}$ & 0.4 & Medium \\
\hline
\end{tabular}

ghum seeds was planted in a hole with $5 \mathrm{~cm}$ deep every $20 \mathrm{~cm}$ in straight lines placed $60 \mathrm{~cm}$ apart (Sahuri, 2017).

\section{Maintenance}

$\mathrm{N}$ Fertilizer was applied twice during growing i.e., at 14 days and at 50 days after planting. At the first fertilizer treatment, $2 / 3$ of the urea dose and half of the TSP and $\mathrm{KCl}$ were used. The remaining was applied in the second fertilizer treatment to stimulate flowering. Fertilizer was dug into the soil in the gaps between the rows of plants (Sahuri, 2017).

\section{Harvesting}

Harvesting was conducted when the sorghum had entered the soft dough phase by cutting the sorghum stem $10-15 \mathrm{~cm}$ above the soil surface.

\section{Variables Observed}

The variables measured were plant morphology (plant height, stem diameter, leaf length, leaf width), stem sugar content, fresh and nutrient production.

\section{Data Analysis}

Data were analyzed using ANOVA for Randomized Block Design by using the SPSS 16 software program, then statistically significant differences were further tested by using Duncan's New Multiple Range Test (Steel \& Torrie, 1997).

\section{RESULTS}

\section{Plant Growth}

Stem diameter $(\mathrm{mm})$, leaf length $(\mathrm{cm})$, leaf width $(\mathrm{cm})$, number of leaves per plant, and plant height $(\mathrm{cm})$ are presented in Table 2. Nitrogen fertilizer had highly significant effects $(\mathrm{p}<0.01)$ on stem diameter, leaf length, leaf width, and leaf number. The plants without nitrogen fertilizer (N0) had the lowest stem diameter, leaf length, leaf width, and leaf number. The stem diameters, leaf lengths, and leaf widths of sorghum treated with the levels of nitrogen fertilizer of 50,100, and $150 \mathrm{~kg}$ $\mathrm{N}$ ha ${ }^{-1}$ were significantly higher $(\mathrm{p}<0.05)$ compared to control sorghum without nitrogen fertilizer. Addition of

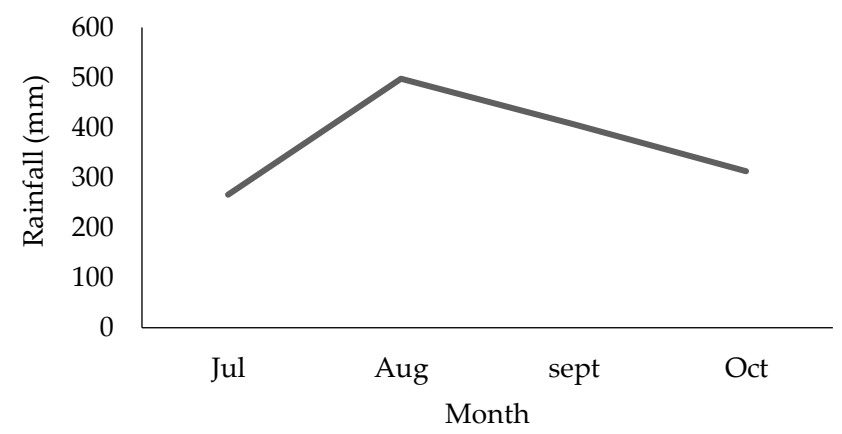

Figure 1. Rainfall (mm) in July to October 2017 
$50 \mathrm{~kg} \mathrm{~N} \mathrm{ha-1} \mathrm{had} \mathrm{similar} \mathrm{leaf} \mathrm{number} \mathrm{to} \mathrm{control} \mathrm{without}$ urea supplementation. However, higher dosages of nitrogen fertilizer (100 and $150 \mathrm{~kg} \mathrm{~N} \mathrm{ha}^{-1}$ ) significantly increased the number of leaves.

\section{Leaves, Stems, Panicles Ratio, and Stem Sugar}

Percentage of the fresh weights at harvest consisted of stem, leaf or panicle along with sugar content of stem are presented in Table 3. The dose of nitrogen fertilizer had a highly significant effect $(\mathrm{p}<0.01)$ on the percentage of the green weight (consisting of leaves and stems). However, the dose of nitrogen fertilizer did not affect panicles. In this study, the addition of nitrogen fertilizer increased the proportion of the green weight consisted of leaves and decreased the proportion of stems. These results are clearly related to the increased number of leaves present in the plants receiving higher levels of $\mathrm{N}$.

\section{Fresh and Nutrient Production}

Averages of production values for fresh production, DM production, and nutrient production (tons ha-1) are presented in Table 4 . The results showed that using nitrogen fertilizer had significant effects $(\mathrm{p}<0.05)$ on fresh and dry matter productions, as well as crude protein $(\mathrm{CP})$, ash, nitrogen-free extract (NFE), and total digestible nutrient (TDN) productions. However, nitrogen fertilizer did not have significant effect on crude fiber (CF) and ether extract (EE). In addition, increase in the dose of $\mathrm{N}$ fertilizer above $50 \mathrm{~kg} \mathrm{ha}^{-1}$ had no significant effect on fresh, dry matter, and nutrients yields (ton ha-1) in BMR mutant sorghum line of Patir 3.7.

\section{Nutrient Content}

The effect of nitrogen fertilizer application on nutrient content is presented in Table 5. The results showed that the application of $\mathrm{N}$ fertilizer resulted in a significant decrease in DM content of whole sorghum $(\mathrm{p}<0.05)$. However, the increase in the level of nitrogen fertilizer has no significant effect on DM content. The application of nitrogen fertilizer did not affect $\mathrm{CP}, \mathrm{CF}, \mathrm{EE}$, ash, and NFE contents.

\section{DISCUSSION}

The significant increase in stem diameter and leaf length and width in BMR mutant sorghum line of Patir 3.7 supplemented with nitrogen fertilizer is related to the sufficient nitrogen availability required for the growth of leaves and stems. Nitrogen is needed for the synthesis of chlorophyll that essential in the photosynthesis producing glucose that provides both the carbohydrates and energy necessary for vegetative growth through the cell division that eventually increase the cell size necessary for both leaf and stem (Almodares et al., 2006; Almodares et al., 2008; Mahdi et al., 2011). Almorades et al. (2008) find that nitrogen application also increases the stem diameter of sweet sorghum and Ayub et al. (2009) records a similar result in pearl millet. In this study, no significant difference was found in plant growth with the use of fertilizer above the lowest dose even though the number of leaves produced increased significantly. The increased level of $\mathrm{N}$ fertilizer above $50 \mathrm{~kg} \mathrm{ha}^{-1}$ did not affect the number of the leaves, size of leaves, and stems. These results are in line with the results reported by Restelatto et al. (2015) that there was a decrease in efficiency with the increase in nitrogen rates in sorghum and oat.

Stem diameters obtained were in the range of 14.90$17.83 \mathrm{~mm}$, leaf widths were in the range of 7.03-8.33 $\mathrm{cm}$, and leaf lengths were in the range of 90.18-101.29 $\mathrm{cm}$. These values are very similar to those reported by Sriagtula et al. (2016) that ranges of stem diameters, leaf widths, and leaf lengths were 16.93-17.35 mm, 7.56-8.04

Table 2. Growth variables of BMR sorghum mutant line Patir 3.7 with different levels of nitrogen fertilizer

\begin{tabular}{cccccc}
\hline \multirow{2}{*}{ Treatments } & \multicolumn{5}{c}{ Growth variables } \\
\cline { 2 - 6 } & Stem diameter $(\mathrm{mm})$ & Leaf length $(\mathrm{cm})$ & Leaf width $(\mathrm{cm})$ & Number of leaf & Plant height $(\mathrm{cm})$ \\
\hline N0 & $15.21 \pm 1.98^{\mathrm{A}}$ & $91.76 \pm 5.82^{\mathrm{A}}$ & $7.20 \pm 0.98^{\mathrm{A}}$ & $6.05 \pm 0.70^{\mathrm{A}}$ & $166.54 \pm 9.39^{\mathrm{A}}$ \\
N1 & $17.89 \pm 2.6^{\mathrm{B}}$ & $98.32 \pm 5.44^{\mathrm{B}}$ & $8.40 \pm 0.88^{\mathrm{B}}$ & $6.63 \pm 0.92^{\mathrm{AB}}$ & $181.77 \pm 12.59^{\mathrm{B}}$ \\
N2 & $17.56 \pm 2.2^{\mathrm{B}}$ & $101.29 \pm 12.07^{\mathrm{B}}$ & $8.27 \pm 1.00^{\mathrm{B}}$ & $6.76 \pm 0.85^{\mathrm{AB}}$ & $183.35 \pm 11.60^{\mathrm{B}}$ \\
N3 & $17.41 \pm 2.04^{\mathrm{B}}$ & $98.78 \pm 12.39^{\mathrm{AB}}$ & $8.25 \pm 0.92^{\mathrm{B}}$ & $7.18 \pm 0.68^{\mathrm{C}}$ & $171.07 \pm 7.64^{\mathrm{A}}$ \\
\hline
\end{tabular}

Note: Means in the same column with different superscripts differ significantly $(\mathrm{p}<0.01)$. N0 $=0 \mathrm{~kg} \mathrm{~N} \mathrm{ha}^{-1}, \mathrm{~N} 1=50 \mathrm{~kg} \mathrm{~N} \mathrm{ha}^{-1}, \mathrm{~N} 2=100 \mathrm{~kg} \mathrm{~N} \mathrm{ha}{ }^{-1}$, and N3= $150 \mathrm{~kg} \mathrm{~N} \mathrm{ha-1}$

Table 3. Leaves, stems, and panicles ratio (fresh weight basis) as well as stem sugar (\% Brix) on BMR sorghum mutant line Patir 3.7 with different levels of nitrogen fertilizer

\begin{tabular}{ccccc}
\hline \multirow{2}{*}{ Treatments } & \multicolumn{4}{c}{ Variables } \\
\cline { 2 - 5 } & Stem ratio (\%) & Leaf ratio $(\%)$ & Panicle ratio (\%) & Stem sugar (\% Brix) \\
\hline N0 & $58.84 \pm 3.76^{\mathrm{C}}$ & $21.88 \pm 2.99^{\mathrm{A}}$ & $19.28 \pm 2.16$ & $10.60 \pm 2.44$ \\
N1 & $56.57 \pm 3.05^{\mathrm{B}}$ & $24.80 \pm 3.32^{\mathrm{B}}$ & $18.63 \pm 1.84$ & $10.09 \pm 2.65$ \\
N2 & $55.97 \pm 5.06^{\mathrm{B}}$ & $24.31 \pm 4.98^{\mathrm{B}}$ & $19.72 \pm 2.32$ & $10.35 \pm 1.83$ \\
N3 & $52.03 \pm 3.75^{\mathrm{A}}$ & $28.81 \pm 2.67^{\mathrm{C}}$ & $19.15 \pm 2.56$ & $10.78 \pm 1.84$ \\
\hline
\end{tabular}

Note: Means in the same column with different superscripts differ significantly $(\mathrm{p}<0.01) . \mathrm{N} 0=0 \mathrm{~kg} \mathrm{~N} \mathrm{ha}{ }^{-1}, \mathrm{~N} 1=50 \mathrm{~kg} \mathrm{~N}$ ha ${ }^{-1}, \mathrm{~N}^{2}=100 \mathrm{~kg} \mathrm{~N}$ ha ${ }^{-1}$, and N3= $150 \mathrm{~kg} \mathrm{~N} \mathrm{ha}^{-1}$ 
Table 4. Biomass and nutrient production of BMR sorghum mutant line Patir 3.7 with different levels of nitrogen fertilizer

\begin{tabular}{lccccc}
\hline \multirow{2}{*}{\multicolumn{1}{c}{ Variables (ton ha $\mathrm{a}^{-1}$ ) }} & \multicolumn{5}{c}{ Treatments } \\
\cline { 2 - 6 } & $\mathrm{N} 0$ & $\mathrm{~N} 1$ & $\mathrm{~N} 2$ & $\mathrm{~N} 3$ & Mean \\
\hline Fresh production & $24.75 \pm 0.50^{\mathrm{a}}$ & $35.77 \pm 3.71^{\mathrm{b}}$ & $34.23 \pm 1.76^{\mathrm{b}}$ & $35.10 \pm 3.32^{\mathrm{b}}$ & $33.16 \pm 4.82$ \\
Dry matter production & $6.70 \pm 0.35^{\mathrm{a}}$ & $8.30 \pm 0.33^{\mathrm{b}}$ & $8.70 \pm 0.02^{\mathrm{b}}$ & $7.91 \pm 0.40^{\mathrm{b}}$ & $7.92 \pm 0.73$ \\
Crude protein production & $0.46 \pm 0.14^{\mathrm{a}}$ & $0.69 \pm 0.12^{\mathrm{b}}$ & $0.70 \pm 0.07^{\mathrm{b}}$ & $0.66 \pm 0.87 \mathrm{~b}$ & $0.65 \pm 0.12$ \\
Crude fiber production & $1.46 \pm 0.01$ & $1.62 \pm 0.10$ & $1.53 \pm 0.15$ & $1.64 \pm 0.10$ & $1.57 \pm 0.12$ \\
Ether extract production & $0.21 \pm 0.00$ & $0.28 \pm 0.02$ & $0.25 \pm 0.09$ & $0.29 \pm 0.01$ & $0.26 \pm 0.05$ \\
Ash production & $0.24 \pm 0.23^{\mathrm{a}}$ & $0.44 \pm 0.09 \mathrm{~b}$ & $0.42 \pm 0.05^{\mathrm{b}}$ & $0.43 \pm 0.09 \mathrm{~b}$ & $0.39 \pm 0.10$ \\
Nitrogen-free extract production & $4.33 \pm 0.28^{\mathrm{a}}$ & $5.49 \pm 0.37^{\mathrm{b}}$ & $5.40 \pm 0.42^{\mathrm{b}}$ & $4.89 \pm 0.38^{\mathrm{ab}}$ & $5.09 \pm 0.55$ \\
Total digestible nutrient production & $4.14 \pm 0.21^{\mathrm{a}}$ & $5.41 \pm 0.45^{\mathrm{b}}$ & $5.39 \pm 0.21^{\mathrm{b}}$ & $4.96 \pm 0.17^{\mathrm{b}}$ & $5.05 \pm 0.55$ \\
\hline
\end{tabular}

Note: Means in the same row with different superscripts differ significantly $(\mathrm{p}<0.05)$. N0= $0 \mathrm{~kg} \mathrm{~N} \mathrm{ha}^{-1}, \mathrm{~N} 1=50 \mathrm{~kg} \mathrm{~N} \mathrm{ha}{ }^{-1}, \mathrm{~N} 2=100 \mathrm{~kg} \mathrm{~N}$ ha-1, and N3= $150 \mathrm{~kg} \mathrm{~N} \mathrm{ha}^{-1}$

Table 5. Nutrients content of BMR sorghum mutant line Patir $3.7\left(\right.$ ton ha $\left.^{-1}\right)$ with different levels of nitrogen fertilizer

\begin{tabular}{lrrrrr}
\hline \multicolumn{1}{c}{ Nutrients (\%) } & \multicolumn{5}{c}{ Treatments } \\
\cline { 2 - 6 } & \multicolumn{1}{c}{$\mathrm{N} 0$} & $\mathrm{~N} 1$ & $\mathrm{~N} 2$ & $\mathrm{~N} 3$ & \multicolumn{1}{c}{ Mean } \\
\hline Dry matter & $27.08 \pm 0.84^{\mathrm{b}}$ & $23.32 \pm 2.01^{\mathrm{a}}$ & $24.41 \pm 1.19^{\mathrm{a}}$ & $22.66 \pm 2.37^{\mathrm{a}}$ & $24.12 \pm 2.21$ \\
Crude protein & $6.84 \pm 0.12$ & $8.37 \pm 1.18$ & $8.40 \pm 0.27$ & $8.39 \pm 1.48$ & $8.10 \pm 1.06$ \\
Crude fiber & $21.83 \pm 0.88$ & $19.65 \pm 2.25$ & $18.29 \pm 0.77$ & $20.27 \pm 1.23$ & $26.02 \pm 1.75$ \\
Ether extract & $3.16 \pm 0.17$ & $3.38 \pm 0.21$ & $2.85 \pm 1.07$ & $3.64 \pm 0.31$ & $3.31 \pm 0.50$ \\
Ash & $3.54 \pm 0.23$ & $5.23 \pm 0.96$ & $4.98 \pm 0.35$ & $5.42 \pm 1.00$ & $4.91 \pm 0.95$ \\
Nitrogen-free extract & $64.65 \pm 0.93$ & $64.52 \pm 0.95$ & $64.67 \pm 0.69$ & $61.78 \pm 1.72$ & $63.77 \pm 1.69$ \\
Total digestible nutrient & $61.81 \pm 0.09$ & $63.03 \pm 1.59$ & $64.62 \pm 3.75$ & $62.68 \pm 1.21$ & $63.16 \pm 2.22$ \\
\hline
\end{tabular}

Note: Means in the same row with different superscripts differ significantly (p<0.05). N0=0 kg N ha ${ }^{-1}, \mathrm{~N} 1=50 \mathrm{~kg} \mathrm{~N} \mathrm{ha}^{-1}, \mathrm{~N} 2=100 \mathrm{~kg} \mathrm{~N}$ ha ${ }^{-1}$ and N3= $150 \mathrm{~kg} \mathrm{~N} \mathrm{ha-1}$

$\mathrm{cm}$, and 100.62-101.72 $\mathrm{cm}$, respectively. However, the range of plants heights in this study was 164.86-184.18 $\mathrm{cm}$ that was lower than that reported by Sriagtula et al. (2016) i.e., $214.38 \mathrm{~cm}$. The relatively low heights of plants in this study appear to be related to the differences in either climatic or soil type. In the present study, the type of soil used was red clay soil (ultisol soil). This soil is classed as marginal and is relatively acidic. In addition, this study was conducted in dry conditions with low rainfall while the study of Sriagtula et al. (2016) was conducted in the rainy season.

Addition of nitrogen fertilizer did not have a significant effect on the sugar contents of the stems. Previous studies also reported that the addition of nitrogen fertilizer did not significantly affect the sugar content in sweet sorghum stems (Maw et al., 2016; Almodares et al. 2008). Sugar content is known to be more influenced by the phosphorus and potassium levels (Ali \& Anjum, 2017) as well as the genetic factors.

The increase in the fresh production of sorghum biomass in this study is contributed by the increased stem diameter, leaf length, leaf width, number of leaves, and plant height with the increased levels of nitrogen fertilizer (Table 1). The increase in dry matter in this study was related to the high photosynthesis rate with the increased nitrogen fertilizer addition similar to mineral uptake in the plant to grow. Mahdi et al. (2011) reported that nitrogen fertilizer in maize could increase plant height, stem thickness, accumulation of dry matter, and production per hectare. Latifmanesh et al. (2018) stated the net photosynthetic rates increased the dry matter accumulation.

The increase in nutrient production with nitrogen fertilizer treatment is caused by the increased of dry matter production. The nutrient productions $(\mathrm{CP}, \mathrm{CF}$, EE, ash, NFE, and TDN) were calculated from the percentage content of nutrients and then multiplied by the average dry matter (DM) production of biomass (tons ha-1). Balabanli et al. (2010) state that the nutrient production of feed crops depend on DM production and nutrients content of plants. The fresh, dry matter, and nutrient productions in this study were lower than those reported by Sriagtula et al. (2016b) and these differences were related to different locations and climate conditions. The study was carried out from July to October 2017 with low to medium rainfall in the range of 100-300 $\mathrm{mm}$.

The lower DM content in the BMR mutant sorghum line of Patir 3.7 receiving nitrogen fertilizer was due to the higher plant growth as was reflected by the higher fresh weight production than the control sorghum without the addition of nitrogen fertilizer. The level of water and nutrients uptakes in plants for metabolism is the combination effects of development and increase in plant tissue such as the number of leaves, leaf area, and plant height as are reflected in the increased fresh weight. The application of nitrogen fertilizer at the levels of 50,100, and $150 \mathrm{~kg} \mathrm{~N} \mathrm{ha}^{-1}$ produced the lower DM content in this study similar to the results reported by Saini (2012) that the increased application of nitrogen 
fertilizer increased moisture content by $75.9 \%(24.1 \%$ $\mathrm{DM})$. Nitrogen plays a role in vegetative growths of stem, leave, and root. Saini (2012) states that nitrogen functions to increase the root growth due to the increased area for absorbing water on the soil profile that eventually increases the water content in the plant.

Even though the content of DM sorghum biomass in control or BMR mutant sorghum line of Patir 3.7 without $\mathrm{N}$ fertilizer (N0) was higher, the other nutrients such as CP, CF, EE, ash, NFE, and TDN were not significantly affected by the addition of nitrogen fertilizer at the levels of 50,100, and $150 \mathrm{~kg} \mathrm{~N}$ ha $^{-1}$ (N1, N2, and N3) because nutrients availabilities in the soil were still sufficient to assimilate nutrient compounds. The results of soil analysis (Table 1) indicate that the soil has a moderate acidity ( $\mathrm{pH}$ 5.6) so that the soil factor supports the growth and production of sorghum plants. Ishak's et al. (2012) states that the zone of land suitability for sorghum ranges from $\mathrm{pH} 5.5$ to 8.5. At $\mathrm{pH} 5.5$, the nutrient content is sufficiently available for plant growth in the tropics, and the growth of soil microorganisms that play roles in the process of nutrient supply is also quite good (Hardjowigeno, 2003). This result is in line with the research of Khalil et al. (2015) stating that cultivation of sweet sorghum requires a relatively low nutrient input.

In this study, the application of nitrogen fertilizer gave an increase in growth parameters (Table 1) and biomass production (fresh and dry matter productions). In general, nitrogen is a limiting nutrient in crop production, and especially in sorghum, nitrogen is the most responsive nutrient for production. This assumption is in line with the statement of Almodares et al. (2006) that the application of nitrogen fertilizer generally increases leaf area, total dry matter, and production of sweet sorghum varieties. However, the nutrient content in this study was not affected by the application of nitrogen fertilizer, except DM content. This result is contradictive with the report of Almodares et al. (2009) that the application of nitrogen fertilizer increases the CP, NFE, and CF content. Olugbemi (2017) states that the different effects of the application of nitrogen in sorghum plants can be due to differences in climate, soil, genotypic factors, season, and location. The DM, CP, and ash contents of BMR sorghum mutant line Patir 3.7 in this study were similar to those reported by Telleng et al. (2016) i.e., $25.26 \%, 9.76 \%$, and $6.76 \%$, respectively.

\section{CONCLUSION}

The nitrogen fertilizer increased the growth of BMR sorghum Patir line 3.7; it increased the ratio of leaves to stems and increased the production of fresh and dry matter biomass. The nutrients production increased with the addition of nitrogen fertilizer except for $\mathrm{CF}$ and EE. The best level of nitrogen fertilizer was $50 \mathrm{~kg} \mathrm{~N} \mathrm{ha}^{-1}$. Therefore, while the use of nitrogen fertilizer is important, there appears to be no advantage in using higher levels of nitrogen fertilizer when BMR mutant sorghum line Patir 3.7 are planted on ultisol soil.

\section{CONFLICT OF INTEREST}

We certify that there is no conflict of interest with any financial, personal, or other relationships with other people or organization related to the material discussed in the manuscript.

\section{ACKNOWLEDGEMENT}

This study was funded by BOPTN Andalas University under Applied Research Scheme 2017, Project ID No. 05/UN.16.17/RT/LPPM. We gratefully acknowledge to Dr. Ir. Supriyanto for supplying Patir 3.7 seeds.

\section{REFERENCES}

Ali, M. \& M.M. Anjum. 2017. Effect of different nitrogen rates on growth, yield and quality of maize. Middle East J. Agric. Res. 6: 107-112.

Almodares, A. \& S.M.M. Darany. 2006. Effects of planting date and time of nitrogen application on yield and sugar content of sweet sorghum. Journal of Environmental Biology 27: $601-605$.

Almodares, A., R. Taheri., III M. Chung, \& M. Fathi. 2008. The effect of nitrogen and potassium fertilizers on growth parameters and carbohydrate contents of sweet sorghum cultivars. J. Environ. Biol. 29: 849-852.

Almodares, A., M. Jafarinia, \& M.R. Hadi. 2009. The effects nitrogen frtilizer on chemical compotition in corn and sweet sorghum. American-Eurasian J. Agric. Environ. Sci. 6: 441-446.

Ayub, M., M.A. Nadeem, A. Tanveer, \& A. Husnain. 2002. Effect of different levels of nitrogen and harvesting times on the growth, yield and quality of sorghum fodder. Asian J. Plant Sci. 1: 304-307. https://doi.org/10.3923/ ajps.2002.304.307

Ayub, M., M. A. Nadeem, M. Tahir, M. Ibrahim, \& M.N. Aslam. 2009. Effect of nitrogen application and harvesting intervals on forage yield and quality of pearl millet (Pennisetum americanum L.). Pak. J. Life Soc. Sci. 7: 185-189.

Balabanli, C., S. Albayrak, \& O. Yuksel. 2010. Effects of nitrogen, phosphorus and potassium fertilization on the quality and yield of native rangeland. Turk. J. Field Crops 15: 164-168.

Brambilla, D. M., C. Nabinger, T. R. Kunrath, P. C. de Faccio Carvalho, I. J. Carassai, \& M. Cadenazzi. 2012. Impact of nitrogen fertilization on the forage characteristics and beef calf performance on native pasture overseeded with ryegrass. R. Bras. Zootec. 41:528-536. https://doi.org/10.1590/ S1516-35982012000300008

Good, A.G. \& P.H. Beatty. 2011. Fertilizing nature: a tragedy of excess in the commons. PloS Biol. 9, e1001124. https://doi. org/10.1371/journal.pbio.1001124

Hardjowigeno, S. 2003. Ilmu Tanah. Penerbit Akademika Pressindo, Jakarta.

Ishak, M., R. Sudirja. \& A. Ismail. 2012. Zona kesesuaian lahan untuk pengembangan tanaman sorgum manis (Sorghum bicolor (L) Moench) di Kabupaten Sumedang berdasarkan analisis geologi, penggunaan lahan, iklim dan topografi. Bionatura-Jurnal Ilmu-ilmu Hayati dan Fisik 14: 173-183.

Khalil, S.R.A., A.A. Abdelhafez, \& E.A.M. Amer. 2015. Evaluation of bioethanol production from juice and bagasse of some sweet sorghum varieties. Ann. Agric. Sci. 60: 317-324. https://doi.org/10.1016/j.aoas.2015.10.005 
Koten, B.B., R. D Soetrisno, N. Ngadiyono, \& B. Suwignyo. 2012. Produksi tanaman sorgum (Sorghum bicolor (L.) Moench) varietas lokal rote sebagai hijauan pakan pupuk urea yang berbeda. Buletin Peternakan 36: 150-155. https:// doi.org/10.21059/buletinpeternak.v36i3.1622

Kurai, T., S.R. Morey., S.P. Wani, \& T. Watanabe. 2015. Efficient rates of nitrogenous fertiliser for irrigated sweet sorghum cultivation during the post-rainy season in the semi-arid tropics. J. Agronomy 71: 63-72. https://doi.org/10.1016/j. eja.2015.07.010

Latifmanesha, H., A. Denga., M. M. Nawaza., L. Li. , Z. Chenb., Y. Zhengb., P. Wangb., Z. Songa., J. Zhanga., C. Zhenga, \& W. Zhanga. 2018. Integrative impacts of rotational tillage on wheat yield and dry matter accumulation under corn-wheat cropping system. Soil Tillage Res. 184: 100108. https://doi.org/10.1016/j.still.2018.07.008

Lakitan, B. 2004. Dasar-Dasar Fisiologi Tumbuhan. Cetakan kelima PT. Raja Grafindo Persada, Jakarta.

Mahdi, S.S., B. Hasan., R.A. Bhat., M.A. Aziz., L. Singh., F.U. Rasool., I. Aalum., L. Singh, \& S. Bashir. 2011. Effect of nitrogen, zinc and seed rate on growth dynamics and yield of fodder.maize (Zea mays L.) under temperate conditions. Plant Archives. 11: 965-971.

Maw, M.J.W., J.H. Houx III, \& F.B. Fritschi. 2016 Sweet sorghum ethanol yield component response to nitrogen fertilization. Ind. Crops Prod. 84: 43-49. https://doi.org/10.1016/j. indcrop.2016.01.038

Olugbemi, O. 2017. Sweet sorghum and nitrogen fertilizer application - A Review. J. Agric. Sci. 2: 28-35.

Ouda, J.O., G.K. Njehia, A.R. Moss, H.M. Omed, \& I.V. Nsahlai. 2005. The nutritive value of forage sorghum genotypes developed for the dry tropical highlands of Kenya as feed source for ruminants. S. Afr. J. Anim Sci. 35: 55-60. https://doi.org/10.4314/sajas.v35i1.4049

Restelatto, R., S. M. Einsfeld., P. S. Pavinato., L. R. Sartor, \& F. P. Baldicera. 2015. Nitrogen efficiency and nutrient absorption by a sorghum-oats forage succession. Advances in Agriculture 2015: 1-12, Article ID 702650. https://doi. org/10.1155/2015/702650

Rocateli, A.C., R. Raper., K.S. Balkcom., F.J. Arriaga., \& D.I. Bransby. 2012. Biomass sorghum production and components under different irrigation/tillage systems for the southeastern U.S. J. Ind. Crop Prod. 36: 589-598. https://doi.org/10.1016/j.indcrop.2011.11.007

Sahuri. 2017. Uji adaptasi sorgum manis sebagai tanaman sela diantara tanaman karet belum menghasilkan. Jurnal Penelitian Karet 35: 23-38. https://doi.org/10.22302/ppk. jpk.v1i1.286

Sriagtula, R., P.D.M. Karti, L. Abdullah, Supriyanto, \& D.A. Astuti. 2016. Dynamics of fiber fraction in generative stage of M10-BMR sorghum mutant lines. International Journal of Sciences: Basic and Applied Research (IJSBAR), 25: 58-69.

Sriagtula, R., P.D.M.H. Karti, L. Abdullah, Supriyanto, \& D.A. Astuti. 2016b. Growth, biomass and nutrient production of brown midrib sorghum mutant lines at different harvest times. Pak. J. Nutr. 15: 524-531. https://doi.org/10.3923/ pjn.2016.524.531

Saini, A. 2012. Forage quality of sorghum (Sorghum bicolor) as influenced by irrigation, nitrogen levels and harveting stage. Indian J. Sci. Res.3: 67-72.

Steel, R. G. D, \& J. H. Torri. 1997. Prinsip dan Prosedur Statistika: Suatu Pendekatan Biometrik. Edisi II. Terjemahan: B. Sumantri. PT. Gramedia Pustaka Utama, Jakarta.

Telleng, M., K. G. Wiryawan, P. D. M. H. Karti, I. G. Permana, \& L. Abdullah. 2016. Forage production and nutrient composition of different sorghum varieties cultivated with indigofera in intercropping system. Med. Pet. 39:203-209. https://doi.org/10.5398/medpet.2016.39.3.203

Turmudhi, E. 2010. Respon pertumbuhan dan hasil tanaman sorgum (Shorgum bicolor) terhadap frekuensi dan dosis pupuk nitrogen. Biofarm Jurnal Ilmiah Pertanian 13: 11-24.

Uchino, H., T. Watanabe, K. Ramu, K. L. Sahrawat, S. Marimuthu, S. P. Wani, \& O. Ito. 2013. Effects of nitrogen application on sweet sorghum (Sorghum bicolor (L.) Moench) in the semi-arid tropical Zone of India. Jpn. Agric. Res. Q. 47: 65-73. https://doi.org/10.6090/jarq.47.65

Yu, J. L., X. Zhang, \& T.W. Tan. 2008. Ethanol production by solid state fermentation of sweet sorghum using thermotolerant yeast strain. Fuel Processing Technology 89: 1056-1059. https://doi.org/10.1016/j.fuproc.2008.04.008 